\title{
The future of European research
}

\author{
With a new research commissioner arriving in Brussels, and big policy changes on the cards, Nature \\ explains how scientists could be affected.
}

Despite having no background in science, Máire Geoghegan-Quinn is about to become one of the most powerful people in European research. This week, she begins work as Europe's research commissioner, replacing Janez Potočnik, and faces the mammoth task of revamping the programmes that fund scientists across the European Union (EU). She arrives at the European Commission at the beginning of a major rethink on science policy that will affect almost every scientist in the union, and their collaborations with partners around the world.

One of her immediate challenges will be to preside over the design of the Eighth Framework Programme of Research (FP8), due to launch in 2014. The framework programmes are the EU's main science-funding mechanism, and FP8 is expected to spend $€ 50$ billion-100 billion (US $\$ 68$ billion-137 billion) over seven years. European researchers flock to the framework programmes, but are appalled by their convoluted bureaucracy. Scientists from other countries, including the United States, can also win funding from some areas of the programmes.

It is already clear that FP8 will be markedly different from its predecessor: GeogheganQuinn wants to create a less bureaucratic framework that supports EU goals, including the creation of a European Research Area. She also becomes Europe's innovation tsar, coordinating with all research programmes in other directorates such as energy, environment and agriculture. Here, Nature looks at some of the issues that will confront Geoghegan-Quinn as she gets to grips with her brief.

\section{European Research Area}

Enabling the free movement of researchers and funding across national borders became a formal goal of the $\mathrm{EU}$ in 2000 , when the union created the European Research Area (ERA). A functional ERA, with no barrier to researchers moving between EU countries, would open up opportunities for funding and make it easier to hire the best talent regardless of nationality.

But ERA has proved difficult to implement, and still requires numerous legal changes by national governments. Most national funding agencies cannot transfer their money to other countries, and it remains almost impossible to transfer pensions. And money is tight. When

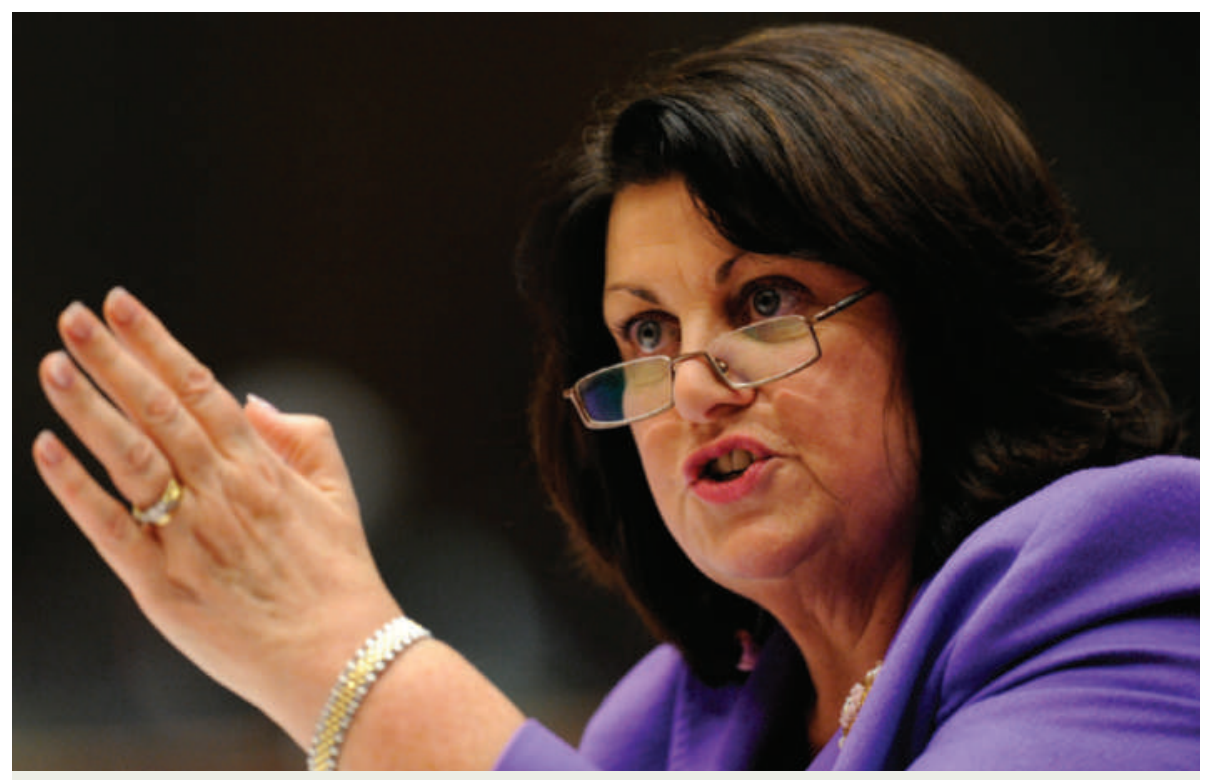

Máire Geoghegan-Quinn (pronounced Moira Gey-gan-Quinn) is an unknown quantity in European research affairs. She held ministerial positions in several Irish governments in the 1980s and 90 s before moving to the European Court of Auditors in 1999. She has also been a columnist for the Irish Times, and in 1996 published a novel, The Green Diamond, set in Dublin.

the European Council of Ministers created ERA, they pledged to support the scheme by raising national research budgets to $3 \%$ of gross domestic product (GDP) by 2010. But the EU's investment in research rose from $1.82 \%$ of GDP in 2000 to only $1.9 \%$ in 2008 . Ministers are now working on a ten-year strategy called EU 2020 that will make ERA more achievable.

\section{European Research Council}

Launched in 2007 as an investigator-driven research agency along the lines of the US National Science Foundation, the European Research Council is popular with scientists and policy-makers alike.

"Because the grants are given purely on scientific merit it really shows grant winners the degree of recognition they have from their peers," says cell biologist Wieland Huttner of the Max Planck Institute for Molecular Cell Biology and Genetics in Dresden, Germany, who was last month awarded a $€ 2.5$-million ERC Advanced Investigator Grant. "It is such a substantial amount of money, it will allow me to do an intensity of research that I wouldn't have otherwise been able to afford, even at a Max Planck Institute."
The ERC has distributed about $€ 1.7$ billion in individual grants, and is likely to receive continued support in FP8. But the council, despite an annual budget of more than $€ 1$ billion, is underfunded for its mission of strengthening and shaping European research through competitive funding. And increasing the budget might prove tough - new EU members, particularly from the former communist bloc, have done poorly out of the ERC and may seek to cap funding.

\section{Cooperation programmes}

Scientists have a love-hate relationship with the cooperation programmes, which were meant to pave the way for ERA by creating Europe-wide consortia of academic and industry scientists to tackle problems relevant to EU policies, from health to energy.

The programmes take up two-thirds of FP7's cash, and each consortium can involve up to 30 principal investigators in different countries, with up to $€ 12$ million at their disposal. Every aspect of cooperation projects must be documented. Every cent and every research hour must be justified and accounted for, both before and after it has been spent, and plans updated 
annually with explanations of why estimates may have slipped. "It's a world of administration, order, liability, accountability - it's unforgiving, and clashes with the culture of science," says immunologist Maria Masucci from the Karolinska Institute in Stockholm, who has participated in several of these programmes. Yet she hopes they will continue. "Our networks have had a very positive scientific impact on our fields and have sparked collaborations we may not otherwise have had," she says.

The commission has managed to reduce the number of audits required in some five-year programmes, but this is a minor improvement. The European Court of Auditors last year suggested the more radical idea that cooperation programmes should be managed by external agencies, rather than the commission itself.

Some influential commission personnel would, however, be glad to see this element of the framework programme disappear. They argue that a new mechanism called joint programming, whereby programmes are funded by member states instead of the commission, could replace it entirely. "It would be a terrible mistake to go in this direction," says biochemist and Nobel prizewinner Aaron Ciechanover of the Technion Institute of Technology in Haifa, Israel. "It's the only programme that brings together people speaking so many different languages and gets them to work productively."

\section{Joint programming}

Joint programming was proposed by the commission in 2008 to promote ERA. Themes for programmes are selected politically - the first to enter the planning stage is on neurodegenerative diseases - and national research agencies choose whether to buy in.

Many member states like this idea because it allows them to follow their national interests. But some scientists worry that countries will prefer to team up with only a small set of partners, further fragmenting the European research effort. "Countries such as Italy, which are considered unreliable research partners, would be at a disadvantage in joint programming," points out cell biologist Pier Paolo di Fiore of the University of Milan, Italy, who has participated in large cooperation programmes.

\section{GOT A NEWS TIP?}

Send any article ideas for Nature's News section to newstips@nature.com

\section{Infrastructure}

Deciding how to fund research infrastructure such as genomics databases, will be one of the trickiest parts of the FP8 negotiations. These facilities are usually beyond national budgets, and need long-term international funding.

Member states have refused to let the commission commit to this funding, but some politicians will argue for a dedicated budget line in FP8 for infrastructure. There is also $€ 10.2$ billion set aside to fund infrastructure projects within the EU's massive structural funds for poor regions - most of which remains unspent, and must be used by 2013 .

Although Geoghegan-Quinn has not given details about how she will tackle these issues, at her confirmation hearing last month she billed herself as a woman of action. "This is a politician who is in charge of doing things, who wants results and who wants delivery," she told MEPs. "I won't be a mouse, I won't be quiet."

Alison Abbott

See Editorial, page 710.

For an interview with Spain's science minister on her European policy plans, see go.nature.com/1igQ1J 